\title{
The treatment of equine endometritis in studfarm practice
}

\author{
S. W. Ricketts \\ Rossdale \& Partners, Beaufort Cottage Stables, High Street, Newmarket, UK.
}

\begin{abstract}
Summary
Endometritis is a common challenge to the genital health of the broodmare and therefore of importance to the studfarm clinician. The control of specific sexually-transmitted bacterial infections is of fundamental importance to the smooth running of equine studfarms. An understanding of the pathogenesis of opportunist infections is fundamental to accurate diagnosis followed by the application of appropriate and successful treatment regimes, tailored to the individual needs of specific mares, to achieve maximum reproductive efficiency.
\end{abstract}

Keywords: $\quad$ Endometritis, therapy, horse

\begin{abstract}
Die Behandlung der equinen Endometritis in der Praxis
Häufig wird die Geschlechtsgesundheit von Zuchtstuten durch eine Endometritis beeinträchtigt. Für den in der equinen Reproduktion tätigen Tierarzt ist sie daher von großer Bedeutung. Die Kontrolle spezifischer, durch den Deckakt übertragener bakterieller Infektionen ist für einen reibungslosen Ablauf des Zuchtgeschehens von entscheidender Bedeutung. Kenntnisse der Pathogenese opportunistischer Infektionen sind Voraussetzungen für eine akkurate Diagnose als Basis einer angemessenen und damit erfolgreichen Therapie, unter Berücksichtigung der individuellen Bedürfnisse der Stute, und daher für eine maximale Effizienz in der Reproduktion.
\end{abstract}

Schlüsselwörter: Endometritis, Therapie, Pferd

\section{Introduction}

Endometritis is an inflammation of the endometrium characterised by infiltration with polymorphonuclear (acute endometritis) or mononuclear (chronic endometritis) leucocytes. Acute endometritis may be associated with infectious or non-infectious aetiologies, or combinations of both. Infectious aetiologies include the sexually-transmitted (venereai) primary pathogens Taylorella equigenitalis, Klebsiella pneumoniae (capsule types 1, 2 or 5) and Pseudomonas aeruginosa and a wide variety of opportunist aerobic and anaerobic bacteria and fungi, either alone or in synergy. Equine endometritis has not yet been conclusively associated with mycoplasmas, ureaplasmas, chlamydiae or viruses. Non-infectious aetiologies include, sperm, seminal plasma, seminal extenders, air, environmental debris and a variety of medicinal substances that are used to treat endometrial disease.

The normal equine uterus, during periods of sexual inactivity and pregnancy, is a sterile endometritis-free environment. This is not the case during periods of sexual activity and the post-partum involutionary period, when the uterine lumen transiently harbours a wide range of genital skin and environmental contaminant organisms.

\section{Pathogenesis}

\section{Sexually-transmitted endometritis}

The sexually-transmitted primary pathogens Taylorella equigenitalis, Klebsiella pneumoniae (capsule types 1, 2 and 5) and Pseudomonas aeruginosa have the ability to cause acute endometritis in genitally-healthy as well as unhealthy mares. They can cause epidemics which spread from carrier mare to stallion, where the organisms become external genital skin contaminants, and then to other mares at mating. Their isolation is now uncommon in populations of horses where specific preventive programmes are adopted.

\section{Opportunist endometritis}

Equine ejaculation normally occurs through the mare's open oestrous cervix, thus acute endometritis is an inevitable sequel to the deposition of semen, seminal fluids and variable amounts and composition of external genital skin and environmental debris into the uterine lumen at natural mating. Acute endometritis is an inevitable sequel following parturition, when the gradually releasing placenta acts as a 'wick', encouraging the entry of environmental microbes into the uterus and following placental release, when the large involuting uterus, aspirates air and environmental debris and microbes. Genitally-healthy mares resolve transient post-mating endometritis within 72 hours and post-parturient endometritis by the first postpartum oestrus ('foal heat'), using complex uterine natural defence mechanisms, involving leucocytic and inflammatory protein responses, local immunoglobulin responses, well-organised myometrial contractions clearing lumenal fluid and, probably, other as yet not defined factors.

Genitally-unhealthy mares cannot, for a multitude of complex interrelating reasons which remain only partially understood, resolve either post-mating or post-partum endometritis, resulting in persistent endometritis. Individual mares 
with genital abnormality associated with ageing or injury, e.g. pneumovagina, vulval, recto-vaginal or cervical injury, or mares that have impaired local endometrial defence mechanisms, including poor clearance of uterine fluid, are predisposed to developing persistent post-mating or post-parturient acute endometritis, or spontaneously at times which are not associated with these two key reproductive events.

\section{Sequelae}

The inflammatory products of acute endometritis provide an intra-uterine environment which is usually hostile to sperm and/or the conceptus, leading to conception failure or early embryonic loss and resulting in depressed fertility. It is therefore an important cause of equine subfertility.

\section{Diagnosis}

Endometritis is diagnosed by the presence of polymorphonuclear leucocytes in endometrial smears taken during oestrus or in endometrial biopsy samples taken at any stage of the non-pregnant mare's cycle. Ultrasound scan may help to demonstrate the severity of inflammation by the degree of endometrial oedema and the volume and echogenicity of retained lumenal fluid. In endometrial biopsy samples, polymorphonuclear leucocytes are seen in the stratum compactum and migrating between luminal epithelial cells. Luminal epithelial degenerative changes may be seen. Eosinophils may be seen in mares with pneumovagina, delayed post-partum involution or following intra-uterine medication. Acute endometritis indicates an inflammatory response, most commonly associated with bacterial infection and the organism(s) associated with the endometritis is/are determined by endometrial bacteriological examinations.

\section{Treatment}

\section{Sexually-transmitted endometritis}

Treatment of mares for genital infection with Taylorella equigenitalis, Klebsiella pneumoniae (capsule types 1, 2 or 5) or Pseudomonas aeruginosa is required following isolation of infection following routine screening or following the investigation of clinical venereal disease. For mares, it is important to clarify whether they have active endometritis, i.e. uterine infection, or are clitoral/vestibular carriers, or both. Where clitoral carrier status only is suspected, it may be sensible to treat the clitoris/vestibule before examining the uterus, to avoid the risk of transferring infection forward.

Taylorella equigenitalis (Contagious Equine Metritis Organism, CEMO)

Mares with uterine infection are treated with 5-7 days intrauterine irrigations with either a water-soluble mixture contai- ning 5 mega units crystalline benzylpenicillin (Glaxovet Ltd.), with $1 \mathrm{~g}$ neomycin sulphate, 40,000 units polymixin B sulphate and $600 \mathrm{mg}$ furadaltone (available by prescription from Vetoquinol Ltd) in $100 \mathrm{ml}$ sterile water or $1 \mathrm{~g}$ ceftiofur sodium in $20 \mathrm{ml}$ sterile water.

Mares with clitoral infections are treated by $5-7$ days daily clitoral scrubbing with $2 \%$ chlorhexidine (Hibiscrub, Zeneca Ltd.) and packing with nitrofurazone ointment (Fura Dress, Horse Health Products (UK) Ltd) with the clitoris everted from its fossa. If necessary, the mare is tranquillised. Particular care is taken to remove all smegma from the clitoral sinuses and folds. Some mares can become sensitive to chiorhexidine and may develop soreness, so care must be taken not to use stronger solutions. Unfortunately, such intensive antibiotic treatment of the external genitalia may result in super-infection with more resistant organisms such as K. pneumoniae and/or Ps. aeruginosa, both of which may produce sexually transmitted diseases in their own right. To try to avoid this unfortunate sequel, the clitoris and its fossa may be treated with a specifically-made actively-growing broth culture containing a mixture of normal equine external genital microflora, following the course of antibiotic treatment.

\section{Klebsiella pneumoniae}

Mares with uterine infection are treated with 5-7 days intrauterine irrigations with $2 \mathrm{~g}$. gentamycin sulphate in $50 \mathrm{ml}$ sterile water for injection, buffered with an equal volume of $7.5 \%$ sodium bicarbonate solution.

Mares with clitoral infections are first treated by clitorectomy. Experience suggests that the highly folded nature of the clitoris and its fossa invariably precludes successful medical treatment. With the mare tranquillised and restrained in stocks, her tail is bandaged and held to one side by an attendant. The clitoris, its fossa and the perineum are scrubbed with non-antiseptic soap (Lux) and $25 \mathrm{ml}$ 2\% lidocaine is injected around the 'stalk' of the clitoris. The area is then washed again and massaged. The clitoris is retracted with a pair of Aliss' forceps and removed with a pair of curved Mayo scissors, taking care to preserve the vestibular fold above the clitoris, for cosmetic reasons. The empty clitoral fossa is then packed with 3\% gentamicin cream (Cidomycin, Roussel; Genticin, Nicholas). The mare is then treated by daily clitoral scrubbing with non-antiseptic soap, whilst the clitoral fossa is everted, taking care to remove all smegma from its folds. The fossa is then washed with a $1 \%$ aqueous solution of hypochlorite and (following confirmation of the infecting organism's in-vitro antibiotic sensitivity pattern) $3 \%$ gentamicin cream (Cidomycin, Roussel; Genticin, Nicholas) is massaged and packed into the clitoral sinuses and fossa. A 7-10 day treatment programme is usually required. Some mares can become sensitive to gentamicin and may develop soreness. Treatment must be postponed in such cases. Following a full course of treatment, the clitoral fossa is treated with a specifically-made actively-growing broth culture containing a mixture of normal equine external genital microflora, to try to aid rapid re-colonisation with normal flora. 


\section{Pseudomonas aeruginosa}

Mares with uterine infection are treated with 5-7 days intrauterine irrigations with $3.2 \mathrm{~g}$. ticarcillin and clavulanic acid (Timentin, Beecham Research) in $100 \mathrm{ml}$ sterile water for injection.

Mares with clitoral infections are clitorectomised as described above and then treated by daily clitoral scrubbing with non-antiseptic soap, whilst the clitoral fossa is everted, taking care to remove all smegma from its folds. An ultraviolet lamp may be helpful in determining the site and extent of contamination and the response to treatment of Ps. aeruginosa genital infections in mares as many isolates fluoresce. After removing the smegma by washing, the everted fossa is sprayed with $1 \%$ silver nitrate solution (a desiccant), from a household plant sprayer, daily for upto 30 days. Periodically throughout and after this course a specifically-made actively-growing broth culture containing a mixture of normal equine external genital microflora is applied to the fossa, to try to aid rapid re-colonisation with normal flora. Silver nitrate solution appears to give better results for mares than 1\% silver sulphadiazine cream (Flamazine, Smith \& Nephew), which is used for the treatment of Ps. aeruginosa dermatological infections in humans.

Systemic treatment with twice daily intravenous injections of gentamycin sulphate $(4.4 \mathrm{mg} / \mathrm{kg})$, for upto 34 days, has been recommended to treat Ps. aeruginosa and K. pneumoniae genital infections in stallions with reported success and may be tried for intractable infections in mares. This is not without dangers of untoward reactions at the injection sites, or from the alteration of intestinal microflora, which can result in diarrhoea, colic and even death from acute colitis. If systemic antibiotic treatment is necessary, for intractable cases, concurrent oral probiotic therapy is recommended.

To assess the success of treatment for Taylorella equigenitalis, Klebsiella pneumoniae or Pseudomonas aeruginosa, follow-up swab samples are collected from the clitoris, its fossa and sinuses (or the empty clitoral fossa) and the vestibule, starting 7 days after the end of treatment, every two days for three sets of negative swabs. Most mares, if treated according to these schedules, recover from CEM infection without difficulty. Occasionally, repeated treatments are required for some mares with deep-seated infections. Treatment of mares with long-standing K. pneumoniae and/or Ps. aeruginosa infections is by no means so straight unless clitorectomy is performed before medical treatment is attempted.

\section{Control of equine sexually-transmitted (venereal) diseases}

Experience since 1977 has demonstrated that strict application of the HBLB's Codes of Practice and the use of careful hygienic stud management and veterinary examination techniques can prevent introduction of these infections or their spread onto and within studfarms. It cannot be overemphasised that all mares imported for breeding should be thoroughly screened for T. equigenitalis, K. pneumoniae, Ps, aeruginosa and Equine Viral Arteritis before they are sent to a stallion for mating. It is essential that all mares are thoroughly re-screened each season before they are allowed to re-start breeding. The most important steps to take following a positive isolation and/or clinical signs of epidemic venereal disease are to stop breeding operations and to start screening for infection and/or carrier status.

Skilled and hygienic artificial insemination, using non-infected semen, is an obvious control measure for venereal disease in mares where this option is allowed by registration authorities and may need to be re-considered by other registration authorities, if necessitated by future events.

\section{Opportunist endometritis}

The most common organisms isolated from cases of opportunist acute endometritis, on blood and McConkey's agar, after overnight culture under aerobic conditions are Streptococcus zooepidemicus (beta haemolytic), Escherischia coli (haemolytic) and Staphylococcus aureus (coagulase positive. The most common anaerobic isolate from endometrial specimens is Bacteroides fragilis. The equine uterus may harbour obligate anaerobes as surface commensals. These organisms normally inhabit the external genital surfaces of mares and stallions and are periodically introduced into the uterus at mating or in association with genital pathology, e.g. pneumovagina or vagino/cervical injury. They may act as opportunist pathogens, where there is epithelial damage, e.g. during the post-partum involutionary period. Synergism with aerobic bacteria may result in mixed infection and active endometritis, possibly, as in other species, by inhibiting uterine leucocyte phagocytosis, via competition for opsonins. The presence of micro-organisms does not, in itself, confirm endometritis and treatment with intra-uterine antibiotic irrigations is indicated where there is concurrent cytological evidence of acute endometritis. As these organisms are opportunist pathogens, predisposing factors such as pneumovagina or cervical injury/incompetence must also be treated.

The choice of antibiotic preparation for local treatment is based on a 35 day course of daily intrauterine infusion with antibiotic or antiseptic drugs to which at least the aerobic organism or organisms are sensitive, using in-vitro antibiotic sensitivity tests. Anaerobic bacterial culture is time consuming and is not routinely performed in practice. Appropriate treatment must nevertheless take into consideration the likely presence of B. fragilis. Anaerobic species are frequently identified by their antibiotic sensitivity patterns and most strains of $B$. fragilis are resistant to penicillin and the aminoglycoside antibiotics. Nitrofurazone, metronidazole and ceftiofur sodium are active against B. fragilis. In view of these considerations, "first choice" intra-uterine antimicrobial treatments should be deliberately broad spectrum, to take account of mixed infections, and should be water-soluble and non-irritant, since those produced in oily bases, and particularly those produced in chalky pessaries, may cause acute endometritis in their own right. Over the last 25 years a water-soluble mixture containing 5 mega units crystalline benzylpenicillin (Glaxovet Ltd.), with $1 \mathrm{~g}$ neomycin 
sulphate, 40,000 units polymixin B sulphate and $600 \mathrm{mg}$ furadaltone (available by prescription from Vetoquinol Ltd., Bicester) has been found to be particularly, successful against the majority of aerobic and anaerobic isolates from acute endometritis cases. This mixture is dissolved in $100 \mathrm{ml}$ sterile water and warmed to $37^{\circ} \mathrm{C}$ before infusion. It is soluble and absorbable and is non-irritant. Over the last three years, since its availability in the UK, $1 \mathrm{~g}$ ceftiofur sodium in $20 \mathrm{ml}$ sterile water for injection has been used as an alternative option, with similar success. Ceftiofur is similarly water soluble, non-irritant, residue-free and active against the major equine aerobic uterine pathogens and B. fragilis. These two treatment regimes have not lead to significant problems with super-infection with Pseudomonas spp., Klebsiella spp. or Fungal infections. It may be that irritant or residue-producing preparations or vehicles are important causes of these problems and it is believed that clinicians should be just as careful about the suitability of intra-uterine medication as they are with intra-articular medication. Some antibiotics, e.g. amikacin and gentamycin, inhibit leucocyte phagocytosis in vitro and are therefore best avoided for intra-uterine use, unless specifically indicated.

Antibiotic infusions may be made, after hygienic preparation of the perineum and vulva, via a sterile plastic insemination pipette, inserted per vaginam with a gloved hand. The catheter is inserted through the cervix into the uterus along the index finger. Infusion may be made through the catheter via a 100 or $20 \mathrm{ml}$ syringe, as appropriate to the mixture used. Treatment schedules for straightforward post-mating or post-parturient endometritis are usually three daily irrigations, during oestrus.

A sometimes convenient method for more prolonged (3-5 days) treatment of the mare's uterus during dioestrus, more commonly for mares treated following their autumn barren mare examinations, is via an indwelling uterine infuser. Infusers are sterile and disposable and will remain in place providing they are used during dioestrus and the mare does not rub them out. The plastic 'ram's horn' intra-uterine device (IUD), which is used to maintain the position of the infuser cranial to the cervix, is first straightened into the outer tube which is then introduced through the cervix with a gloved arm, per vaginam, along the index finger. The middle tube is then pushed forwards to extrude the IUD, attached to the inner catheter, into the body of the uterus. The outer and middle tubes are then carefully removed leaving the inner catheter in place. The catheter is then sutured to the side of the vulva to maintain its position. Two blebs of local anaesthetic are placed at the junction of the vulva and the buttock, approximately $5 \mathrm{~cm}$ apart. Nylon stay sutures are first placed loosely on the skin and the catheter is then tied on top so that it does not pull tight to the skin, which tends to cause irritation causing the mare to rub the catheter out. Stay sutures are essential as there have been cases, where they have not been used, where the catheter has been assumed "lost" only to be found coiled inside the uterus with signs of pyometra, at a later date. Infusions may be made, through the catheter, using a 60 or $100 \mathrm{ml}$ syringe with a 16 gauge needle attached. The 16 gauge needle fits snuggly in- to the indwelling catheter. The plastic plug should be replaced after each infusion. The catheter is then removed, by removing the sutures and gently pulling the tube. It has been suggested that there may be some beneficial 'foreign body' reaction in the uterus when the infuser is left in place for up to a month or more. There appears to be no evidence, from endometrial biopsy studies, that this is so and, even if it were so, a true granulomatous endometritis might be a disadvantage. Thus, leaving the infuser in place after antibiotic treatment has ended, is considered unwise.

In addition to local treatment with antibiotics, systemic treatment may, on occasions, be indicated. In the experience of most clinicians involved in studfarm practice, systemic antibiotic treatment alone is of little value in the treatment of uterine infection in the mare. In most cases the infecting organism is in the uterine lumen rather than the endometrial tissues and thus local uterine luminal treatment with antibiotics, saline flushing and the promotion of uterine fluid clearance is likely to be most successful.

Where there are signs of uterine fluid accumulation or pyometra, and particularly for the treatment of persistent postmating or post-parturient endometritis, the uterus is flushed with large volumes (3 I) of sterile saline solution, with 3\% hydrogen peroxide added for cases of pyometritis or markedly hyperechoic fluid accumulation, is recommended prior to starting antibiotic treatment. 'To-and-fro' flushing may be performed via an egg-flushing catheter. Uterine fluid clearance is then stimulated with 25 iu oxytocin, given intravenously. Large volume flushing and oxytocin treatment may be repeated daily or, if indicated, twice daily until ultrasound scan examinations suggest resolution.

Where there are no demonstrable physical predisposing factors, and a history of recurrent acute endometritis suggests a local immune defect, experience has suggested that intra-uterine homologous plasma irrigations (a source of opsonins) may be useful for selected cases. This form of treatment remains highly controversial and prior treatment with large volume saline flush and/or antibiotic irrigation is recommended.

The success or failure of treatment for endometritis may be monitored by 'follow-up' endometrial smear/swab examinations at the next oestrous period or biopsy examinations, taken 3-4 weeks after the end of the course of treatment.

For some mares with recurrent non-responsive endometritis, videohysteroscopic examinations have on occasions revealed lumenal foreign bodies consisting of placental remnant, cotton wool (presumably swab tip fragment), amorphous debris with a central core of multiplying bacteria or unidentifiable degenerate debris. Once removed with a biopsy attachment, via the videoscope, these cases have responded to conventional treatment for acute endometritis.

\section{Mycotic endometritis}

Fungal cultures can be performed on Sabaraud's agar. Isolates are sometimes made on simple blood agar plates during aerobic bacterial screening. They are opportunist pa- 
thogens and interpretation of significance depends upon clinical and/or cytological criteria. The most commonly isolated fungal organisms are Candida spp., Aspergillus spp., Mucor spp. and Allescheria boydii.

Fungal infections of the uterus may produce clinical signs which vary from none, in which the infection is luminal and there is no tissue invasion, to severe purulent endometritis, demonstrable by ultrasound scan. Mycotic endometritis can lead to conception failure or, if infection occurs during pregnancy, to abortion. In some cases, there may be quite marked inflammatory changes visible on vaginoscopy, with grey/mucoid pus formation and a markedly inflamed, sometimes congestion/streaked cervix. Endometrial cytological and/or histological evidence of both fungus and acute endometritis is required to confirm the diagnosis.

In mares with normal local uterine defence mechanisms, fungal endometritis usually resolves spontaneously with time. Thus mares with persistent mycotic endometritis are treated by correcting predisposing factor abnormalities, e.g. delayed post-partum uterine involution, pneumovagina or cervical injury, prior to large volume (3 I daily or twice daily) uterine irrigation with sterile saline solution. $3 \%$ hydrogen peroxide solution may be added to the saline to help lift off debris containing fungus which may be adherent to the luminal epithelium. Irrigation with dilute iodine solutions, e.g. $250 \mathrm{ml} \mathrm{10 \%}$ povidone-iodine (1\% available iodine) in saline solution, has been recommended but experience suggests that this may cause quite severe genital inflammation in individual mares and therefore it may be wise to start with a more dilute solution ( $0.5 \%$ povidone iodine) and then assess the response before continuing. Following treatment and recovery (based upon negative endometrial swab and smear tests), when appropriate, such mares are treated before and after mating with appropriate prophylactic minimal contamination breeding techniques.

The use of specific antimycotic agents, e.g. amphoteracin B (0.03-1.00 ug/ml), nystatin (100 units $/ \mathrm{ml})$ in solution or suspension and nystatin, clotrimazole and econazole human intra-vaginal pessaries has not been critically evaluated in mares with fungal endometritis. Subjective experience suggests that their increased cost over less specific treatment is not justified by increased efficacy.

\section{Pyometra}

This is an uncommon condition in the UK mare, most frequently associated with cervical injury or abnormality. It has been more frequently reported in North America with chronic Ps. aeruginosa infections, in which the degree of endometrial glandular damage is sometimes so severe that endogenous prostaglandin secretion is insufficient to cause luteolysis and prolonged dioestrus occurs. Unfortunately, both the cervical and endometrial abnormalities are usually difficult to resolve and the condition usually recurs following extensive intrauterine medical treatment. Hysterectomy is the most satisfactory treatment where the mare can be subsequently used for riding or companionship.

\section{Chronic endometritis}

Mononuclear cells, i.e. histiocytes/lymphocytes and plasma cells are seen diffusely and/or in focal stromal aggregations in biopsy specimens. The presence of these cells indicates a local immune response and therefore previous or ongoing antigenic challenge. No specific treatment is indicated for chronic infiltrative endometritis. Rarely, dense diffuse or focal granulomatous-type cellular infiltrations, with large numbers of plasma cell or even multinucleate giant cells have been seen.

Glandular degenerative changes are seen in biopsy specimens in the form of 'nests', surrounded by lamellae of fibrous tissue or, less commonly, 'cysts', lined by glandular epithelial cells. Peri-glandular, peri-vascular or, less commonly, diffuse stromal fibrosis is seen. Diffuse stromal fibrosis is considered to be a poor prognostic signs for the maintenance of future pregnancies. Pools of tissue fluid may be seen scattered in the stroma. Lymphatic 'lacunae', lined by lymphatic endothelial cells, may be seen in the stroma. As they develop they become larger and migrate into the uterine lumen, attached to the endometrium by a 'stalk' of lymphatic duct. These endometrial cysts, when large enough, can be seen by ultrasound scan. It is unusual to sample an endometrial lymphatic cyst, using biopsy techniques, but these are thought to have a similar pathogenesis.

These changes indicate chronic endometrial degenerative disease (CDE or endometrosis). This is a progressive condition associated most importantly with the normal ageing process and its cyclic endocrinological effects. They are not inflammatory conditions and do not therefore constitute endometritis. The horse breeding industry aims for maximum efficiency and owners would like mares to produce single foals annually throughout their lives. However, transient endometritis is an unavoidable consequence of mating or insemination and the natural ageing process, paradoxically accelerated both by reproductive inactivity and by the repeated challenges of coitus, endometritis, pregnancy and parturition, followed by involution, is associated with progressive endometrial degenerative changes. These factors all result in progressive endometrial pathology, which is believed to be a major factor in producing the linear fall in Thoroughbred fertility with age. Nevertheless, a better knowledge of the pathogenesis of progressive endometrial disease, it's treatment and the application of modern managerial and veterinary preventive measures is believed to be at least in part responsible for the comparatively high degree of efficiency now seen in the more intensive areas of the horse breeding industry.

\section{Literature}

Adams G.P. and Ginther O.J. (1989): Efficacy of intrauterine infusion of plasma for treatment of infertility and endometritis in mares. J. Am. Vet. Med. Assn. 194, 372

Adams G.P. Kastelic J.P Bergfelt D.R. et al (1987): Effect of uterine inflammation and ultrasonically-detected uterine pathology on fertility in the mare. J Reprod Fert, Suppl 35, 445.

Allen W.E. (1991): Investigations into the use of oxytocin for promoting uterine drainage in mares susceptible to endometritis. Vet. Record $128,593$. 
Allen W.E. and Pycock J.F. (1988): Cyclical accumulation of uterine fluid in mares with lowered resistance to endometritis. Vet. Record 122, 489

Allen W.E. and Pycock J.F. (1989): Current views on the pathogenesis of bacterial endometritis in mares with lowered resistance to endometritis. Vet. Record 125, 298

Asbury A.C. (1984): Uterine defence mechanisms in the mare: The use of intrauterine plasma in the management of endometritis. Theriogenology 21, 387

Asbury, A.C. (1987): Failure of uterine defence mechanisms. In Current Therapy in Equine Medicine, 2nd. Edit., Ed. N.E. Robinson, W.B. Saunders, Philadelphia, 508-510.

Asbury, A.C., Gorman, N.T. and Foster, G.W. (1984): Uterine defense mechanisms in the mare: serum opsonins affecting phagocytosis of Streptococcus zooepidemicus by equine neutrophils. Theriogenology, 21, 375-383

Asbury, A.C. and Lyle, S.K.. (1993): Infectious caused of infertility. In Equine Reproduction, ed. A.O. McKinnon \& J.L. Voss, Lea \& Febiger. 381-391.

Asbury, A.C., Schultz, K.T., Klesius, P.H., Foster, G.W. and Washburn, S.M. (1982): Factors affecting phagocytosis of bacteria by neutrophils in the mare's uterus. J. Reprod. Fert. Suppl. 32, 151-159.

Blue, M.G. (1987): Fungal endometritis. In Current Therapy in Equine Medicine, 2nd. Edit,, Ed. N.E. Robinson, W.B. Saunders, Philadelphia, 511-512.

Cheung, A.T.W., Liu, I.K.M., Walsh, E.M. and Miller, M.E. (1985): Phagocytic and killing capacities of uterine-derived polymorphonuclear leukocytes from mares resistant and susceptible to chronic endometritis. Am. J. Vet. Res., 46, 1938-1940.

Hughes, J.P. and Loy, R.G. (1969): Investigations on the effect of intrauterine inoculations of Streptococcus zooepidemicus in the mare. Proc. 15th. Ann. Conv. Am. Ass. Equine Practnr., 289-292.

Hughes, J.P. and Loy, R.G. (1975): The relation of infection to infertility in the mare and stallion. Equine Vet. J., 7, 155-159.

Katila T. (1997): Interactions of the uterus and semen. Pferdeheilkunde 13, 508.

Kenney, R.M., Bergman, R.V., Cooper, W.L. and Morse, G.W. (1975): Minimal contamination techniques for breeding mares: technique and preliminary findings. Proc. 21st. An. Conv. Am. Ass. Equine Practnr., 327.

Kotilainen T. Huhtinen M. and Katila T. (1994): Sperm-induced leukocytosis in the equine uterus. Theriogenology 41,629 .

LeBlanc M.M. (1997): Effects of oxytocin, prostaglandin and phenylbutazone on uterine clearance of radiocolloid. Pferdeheilkunde 13 , 483.

LeBlanc, M., Neuwirtz, L., Mauragis, D., Klapstein, E. and Tran, T. (1994): Oxytocin enhances clearance of radiocolloid from the uterine lumen of reproductively normal mares and mares susceptible to endometritis. Equine Vet. J., 26, 279-282.

Mackintosh, M.E. (1981): Bacteriological techniques in the diagnosis of equine genital infections. Vet. Record, 108, 52-55.

Peterson, F.B., McFeely, R.A. and David, J.S.E. (1969): Studies on the pathogenesis of endometritis in the mare. Proc. 15th. Ann. Conv. Am. Ass. Equine Practnr., 279-288.

Pycock J.F. (1994): A new approach to treatment of endometritis. Equine Vet. Education 6, 36

Pycock J.F. (1994): Assessment of oxytocin and intrauterine antibiotics on intrauterine fluid and pregnancy rates in the mare. Proc. 40th Ann. Conv. Am. Ass. Equine Pract., 19.

Pycock J.F. and Allen W.E. (1990): Inflammatory components in uterine fluid from mares with experimentally induced bacterial endometritis. Equine Vet. J. 22, 422.

Pycock J.F. and Newcombe J.R. (1996): The relationship between intraluminal uterine fluid, endometritis and pregnancy rate in the mare. Equine Pract. 18, 19

Pycock J.F. and Newcombe J.R. (1996): Assessment of the effect of three treatments to remove intrauterine fluid on pregnancy rate in the mare. Vet. Record 138, 320.

Pycock J.F. Paccamonti D. Jonker H. et al (1997): Can mares be classified as resistant or susceptible to recurrent endometritis? Pferdeheilkunde 13, 431

Rasch K. Schoon H.A. Sieme et al (1996): Histomorphological endometrial status and influence of oxytocin on the uterine drainage and pregnancy rate in mares. Equine Vet. J. 28, 455.
Ricketts, S.W. (1978): Histological and histopathological studies on the endometrium of the mare. Fellowship Thesis, R.C.V.S., London.

Ricketts, S.W. (1987): Uterine abnormalities. In Current Therapy in Equine Medicine, 2nd. Edit., Ed. N.E. Robinson, W.B. Saunders, PhiladeIphia, 503-507.

Ricketts, S.W. (1989): The barren mare: Diagnosis, prognosis, prophylaxis and treatment for genital abnormality. Part 1. In Practice, 11, 119-125.

Ricketts, S.W. (1989): The barren mare: Diagnosis, prognosis, prophylaxis and treatment for genital abnormality. Part 2. In Practice, 11, 156-164.

Ricketts, S.W. (1996): Contagious Endometritis (CEM). Equine Vet. Education, 8, 166-170.

Ricketts, S.W. (1997): Treatment of equine endometritis with intrauterine irrigations of ceftiofur sodium: a comparison with mares treated in a similar manner with a mixture of sodium benzylpenicillin, neomycin sulphate, polymixin $B$ sulphate and furaltadone hydrochloride. Pferdeheilkunde, 13, 486-489.

Ricketts, S.W. and Alonso, S. (1991): Assessment of the breeding prognosis of mares using paired endometrial biopsy techniques. Equine Vet. J., 23, 185-188.

Ricketts, S.W. and Mackintosh M.E. (1987): The role of anaerobic bacteria in equine endometritis. J. Reprod. Fert., Suppl. 35, 343-351.

Ricketts, S.W., Young, A., and Medici, E.B. (1993): Uterine and clitoral cultures. In Equine Reproduction, ed. A.O. McKinnon \& J.L. Voss, Lea \& Febiger. 234-245.

Rossdale P.D. and Ricketts S.W. (1980): Equine Studfarm Medicine, 2nd. Edit., Bailliere Tindall, London.

Troedsson M.H.T. (1995): Uterine response to semen deposition in the mare. Proc. Soc. Theriogenology, 130

Troedsson M.H.T. and Liu I.K.M. (1991): Uterine clearance of non-antigenic markers $(51-\mathrm{Cr})$ in response to a bacterial challenge in mares potentially susceptible and resistant to chronic uterine infections. J. Reprod. Fert. Suppl. 44, 283.

Troedsson M.H.T., Scott MA and Liu I.K.M. (1992): Pathogenesis and treatment of chronic uterine infection. Proc. 38th Ann. Conv. Am. Ass. Equine Pract., 595.

Troedsson, M.H.T., Liu, I.K.M., Ing, M., Pascoe, J. and Thurmond, M. (1993): Multiple site electromyography recordings of uterine activity following an intrauterine bacterial challenge in mares susceptible and resistant to chronic uterine infection. J. Reprod. Fert., Suppl. 99, 307-313.

Troedsson M.H.T. Scott M.A. and Liu I.K.M. (1995): Comparative treatment of mares susceptible to chronic uterine infection. Am. J. Vet. Research, 56, 468.

Watson, E.D. (1988): Uterine defence mechanisms in mares resistant and susceptible to endometritis: a review. Equine Vet. J., 20, 397-410.

Watson, E.D. and Dixon, C.E. (1993): MHC Class II expression and lymphoid tissue in the endometrium of the mare. Equine Vet. J., 25, 120-124.

Watson, E.D. and Stokes, C.R. (1990): Effect of susceptibility to endo metritis on specific antibody in the endometria of mares. Theriogenology, 34, 39-45.

Watson, E.D., Stokes, C.R. and Bourne, F.J. (1987): Uterine cellular and humoral defence mechanisms in mares susceptible and resistant to persistent endometritis. Vet. Immunol. Immunopathol., 16, 107-121.

Wingfield Digby, N.J. (1978): The technique and clinical interpretation of endometrial cytology in mares, Equine Vet. J., 10, 167-170.

Wingfield Digby N.J. and Ricketts, S.W. (1982): A method for clitoral sinusectomy in mares. In Practice, 4, 145.

Wingfield Digby, N.J. and Ricketts, S.W. (1982): Results of concurrent bacteriological and cytological examinations of the endometrium of mares in routine studfarm practice 1978-1981. J. Reprod. Fert. Suppl. $32,181-185$

Dr. Sidney W. Ricketts LVO, BSc, BVSC, DESM, FRCVS

Beaufort Cottage Stables

High Street

Newmarket, Suffolk, CB8 8JS

UK

Tel.:0044-1638-663150

Fax: 0044-1638-660157 